\title{
KEWENANGAN PEMERINTAH KABUPATEN BADUNG DALAM PENGENDALIAN PERIZINAN PEMBANGUNAN SARANA AKOMODASI PARIWISATA ${ }^{1}$
}

\author{
Oleh: \\ I Made Ari Artaya ${ }^{2}$
}

\begin{abstract}
The rapid development of tourism in Badung Regency requires the development and construction of accommodation facilities and other tourism supporting facilities.It is intended to support tourism and the tourists who visit Badung Regency. Based on the data of the Government of Badung Regency, there was an increased growth of tourism accommodation facilities in 2015 with the details as follows: 98 starred hotels, 885 budget hotels, and 38 condo hotels. A moratorium policy is required to control this very rapid development of construction of tourism accommodation facilities. The Government of Badung Regency follows up on this issue by issuingRegent's Decree No. 36 year 2014 on Minimum Standards for Land Area, Room Area, And Supporting Facilities of Hotels and Condo Hotels. Furthermore, the problem is formulated as follows: What is the source of authority of Badung Regency to control the construction of tourism accommodation facilities? And what kind of policy is used to control the permit of construction of tourism accommodation facilities in Badung Regency? This research uses normative research method to study elements of law including norms, rules, principles of law, doctrines, and legislations. This research uses the statute approach and analytical and conceptual approach. The RTRW of Badung Regency mentions that the authority of the government of Badung Regency in the implementation of control of space utilization in Badung Regency includes arranging general provisions of Zoning Regulations, requirements of permit, provision of incentives and disincentives and guidance of sanctions. One of the permits that are applied to control the construction of tourism accommodation facilities is regulated in section 2 of Regent's Decree No. 36 year 2014.
\end{abstract}

Keywords: Construction of Tourism Accommodation Facilities, Moratorium Policy, Government of Badung Regency.

\begin{abstract}
Abstrak
Pesatnya perkembangan pariwisata di Kabupaten Badung, menuntut pula perkembangan dan pembangunan sarana akomodasi dan fasilitas-fasilitas penunjang pariwisata lainnya. Hal ini merupakan sebuah tujuan untuk mendukung pariwisata dan para wisatawan yang datang ke Kabupaten Badung. Menurut data Badung dalam angka tahun 2015 pertumbuhan sarana akomodasi pariwisata yaitu hotel bintang, hotel melati dan kondotel sampai tahun 2015

\footnotetext{
1 Artikel ini merupakan karya ilmiah mahasiswa pada Program Studi Magister (S2) Ilmu Hukum Program Pascasarjana Universitas Udayana serta mengucapkan terimakasih kepada Prof. Dr. I Wayan Parsa, SH.M.,Hum dan Dr. Putu Gede Arya Sumerthayasa, SH.,MH selaku pembimbing. Denpasar Bali, Email: ari.artaya@gmail.com
}

2 Mahasiswa Program Studi Magister (S2) Ilmu Hukum Program Pascasarjana Universitas Udayana,
\end{abstract}


mengalami peningkatan pertumbuhan yang sangat pesat, pertumbuhan jumlah hotel bintang sampai tahun 2015 sebanyak 98 hotel, pertumbuhan jumlah hotel melati sampai tahun 2015 mencapai 885 hotel dan pertumbuhan jumlah kondotel sampai tahun 2015 mencapai 38 kondotel. Tingginya perkembangan pembangunan sarana akomodasi pariwisata, menuntut dikeluarkannya kebijakan moratorium untuk pengendalian pembangunan sarana akomodasi pariwisata. Untuk itu, Pemerintah Kabupaten Badung menindaklanjuti dengan kebijakan menerbitkan Peraturan Bupati (Perbup) Nomor 36 tahun 2014 tentang Standar minimal luas lahan dan luas kamar serta fasilitas penunjang hotel dan kondotel. Maka dari itu dirumuskan masalah: Apakah yang menjadi sumber kewenangan Pemerintah Daerah Kabupaten Badung dalam pengendalian pembangunan sarana akomodasi pariwisata? Dan Bagaimanakah kebijakan pengendalian perizinan pembangunan sarana akomodasi pariwisata di Kabupaten Badung?. Jenis penelitian ini menggunakan metode penelitian normative yang merupakan penelitian mengenai substansi hukum yang terdiri dari norma, kaidah, asas-asas hukum, doktrin dan peraturan perundang-undangan. Dengan jenis pendekatan menggunakan: The Statute Approach and Analitical and Conceptual Approach. Dalam RTRW Kabupaten Badung disebutkan bahwa Kewenangan Pemerintah Kabupaten Badung dalam pelaksanaan pengendalian pemanfaatan ruang di wilayah Kabupaten Badung yaitu dengan menyusun ketentuan umum Peraturan Zonasi, ketentuan perizinan, ketentuan pemberian insentif dan disinsentif dan arahan sanksi. Salah satu perizinan yang diterapkan untuk pengendalian pembangunan sarana akomodasi pariwisata diatur dalam Pasal 2 Peraturan Bupati (Perbup) Nomor 36 tahun 2014.

Kata Kunci: Pembangunan Sarana Akomodasi Pariwisata, Kebijakan Moratorium, Pemerintahan Kabupaten Badung.

\section{PENDAHULUAN}

Pesatnya perkembangan pariwisata di Bali pada umumnya dan di Kabupaten Badung pada khususnya, menuntut pula perkembangan dan pembangunan sarana akomodasi yang terus berkembang. Penyediaan fasilitas-fasilitas tersebut merupakan sebuah tujuan untuk mendukung pariwisata dan para wisatawan yang datang ke Bali. Penyediaan sarana akomodasi pariwisata (hotel) merupakan prioritas untuk menyokong pembangunan pariwisata di Kabupaten Badung. Menurut data Badung dalam angka tahun 2015, banyaknya wisatawan yang berkunjung ke Kabupaten Badung melalui Bandara Ngurah Rai adalah suatu hal yang positif khususnya yang bergerak pada usaha perhotelan. Selama tahun 2014 jumlah wisatawan yang datang langsung ke Bali sebanyak 3.766.638 orang, naik bila dibandingkan tahun 2013 sebanyak 3.278 .598 orang atau perkembangan kunjungan wisatawan mancanegara yang datang langsung ke Bali dari tahun 2013 sampai 2014 hampir mencapai 3\% kunjungan, sehingga dibutuhkan sarana akomodasi yang harus disediakan untuk bisa menampung kunjungan wisatawan 
tersebut. ${ }^{3}$ Menurut data Badung dalam angka tahun 2015 pertumbuhan sarana akomodasi pariwisata yaitu hotel bintang, hotel melati, pondok wisata dan kondotel sampai tahun 2015 mengalami peningkatan pertumbuhan yang sangat pesat, pertumbuhan jumlah hotel bintang sampai tahun 2015 sebanyak 98 hoteldenganjumlah kamar sebanyak 16.360 kamar, pertumbuhan jumlah hotel melati sampai tahun 2015 mencapai 885 hotel dengan jumlah kamar sebanyak 34.815 kamar, pertumbuhan jumlah pondok wisata sampai 2015 mencapai 999 pondok wisata dengan jumlah kamar sebanyak 3.937 kamar dan pertumbuhan jumlah kondotel sampai tahun 2015 mencapai 38 kondotel dengan jumlah kamar sebanyak 5.141 kamar $^{4}$, yang tersebar di seluruh Kecamatan Kuta Selatan, Kuta dan Kuta Utara di Kabupaten Badung. Dari data tersebut konsentrasi lokasi pertumbuhan hotel dan kondotel berada di wilayah Badung Selatan.

Dengan meningkatkan jumlah kunjungan wisatawan ke Bali dan ke Kabupaten Badung pada khususnya serta perkembangan sarana akomodasi secara tidaklangsung akan memberikan peluang dalam meningkatkan taraf perekonomian bagi masyarakat lokal, memberikan pemasukan bagi daerah (PAD), memperluas lapangan kerja, dan memperkenalkan keindahan alam dan budaya yang dimiliki Bali ke mata dunia.

Badan Pusat Statistik Kabupaten Badung, Badung Dalam Angka Tahun 2015, hlm. 321.

4 Badan Pusat Statistik Kabupaten Badung, Badung Dalam Angka Tahun 2015, hlm. 327
Dari sarana akomodasi yang tumbuh dengan pesat di kawasan Kabupaten Badung, memberikan hal positif terhadap perekonomian Kabupaten Badung. Pajak Hotel dan Pajak Restoran (PHR) yang memberikan kontribusi besar terhadap peningkatan PAD Kabupaten Badung. Hal ini dikarenakan banyaknya hotel dan restoran yang berada di kawasan pariwisata di Kabupaten Badung. Menurut data Badan Perencana Pembangunan Daerah (Bappeda) Kabupaten Badung, dari tahun 2010 hingga tahun 2016 PAD Kabupaten terus mengalami peningkatan yang signifikan mencapai 3,9 triliun rupiah.

Namun dengan berkembangnya jumlah kunjungan wisatawan dan bertambahnya sarana akomodasi di Kabupaten Badung tidak dampak positif saja yang ditimbulkan, akan tetapi juga menimbulkan dampak yang negatif pula, dengan maraknya pembangunan hotel sehingga akan berakibat terjadinya perang tariff, akibat tak seimbangnya supply and demand. Jika terus dibiarkan perkembangan pertumbuhan sarana akomodasi pariwisata khususnya di Kabupaten Badung lama kelamaan beban industry pariwisata akan makin tinggi akibat persaingan yang tidak sehat, belum lagi dibarengi dengan tidak memadainya infrastruktur jalan, banjir, macet dan kebutuhan akan air bersih serta aspek lingkungan yang kurang nyaman dan bersih.

Tingginya perkembangan 
pembangunan sarana akomodasi pariwisata khususnya di wilayah Badung Selatan, maka dirasa perlu adanya kebijakan moratorium dalam pembangunan sarana akomodasi pariwisata yaitu pengendalian pembangunan sarana akomodasi pariwisata dan pemerintah mengevaluasi pembangunan tersebut dalam rentan waktu yang ditentukan. Kebijakan Moratorium ini diterapkan di wilayah Badung Selatan. Karena di wilayah Badung Selatan ini mengalami pertumbuhan akomodasi pariwisata yang pesat dan tidak terkendali sehingga mengalami "overcapacity".

Kebijakan

moratorium

pembangunan sarana akomodasi akomodasi ini juga dengan harapan agar pembangunan hotel dan kondotel serta fasilitas penunjang pariwisata lainnya, agar mempunyai kualitas dan mencerminkan kearifan lokal serta mencegah menjamurnya konsep city hotel yang tidak bisa dibendung perkembangannya. Disamping itu, kebijakan ini dikeluarkan untuk menindaklanjuti daripada kebijakan moratoriumakomodasipariwisatayang dikeluarkan oleh Pemerintah Provinsi Bali ini mengacu pada Surat Edaran (SE) Gubernur Bali No.570/1665/BPM tanggal 27 Desember 2010 tentang penghentian sementara pembangunan akomodasi pariwisata dan penanaman modal untuk bidang jasa akomodasi. Kebijakan moratorium ini berlaku sejak 5 Januari 2011. Surat Edaran tersebut dilayangkan dan agar segera ditindak lanjuti oleh Kota Denpasar, Kabupaten Gianyar dan Kabupaten Badung. Karena pada ketiga wilayah tersebut mengalami kejenuhan pembangunan sarana akomodasi pariwisata dan pertumbuhan pembangunan sarana akomodasi yang tidak terkendali. Maka dari itu Pemerintah Daerah Provinsi Bali perlu mengeluarkan kebijakan moratorium ini agar dapat mengevaluasi pembangunan sarana akomodasi pariwisata yang telah terjadi selama ini. Oleh karena itu, Pemerintah Kabupaten Badung menindaklanjuti kebijakan tersebut dengan menerbitkan Peraturan Bupati (Perbup) Nomor 36 tahun 2014 tentang Standar minimal luas lahan dan luas kamar serta fasilitas penunjang hotel dan kondotel. Dari uraian latar belakang yang telah dijelaskan di atas maka dapat ditarik rumusan masalah sebagai berikut :

1. Apakah yang menjadi sumber kewenangan Pemerintah Daerah Kabupaten Badung dalam pengendalian perizinan pembangunan sarana akomodasi pariwisata?

2. Bagaimanakah kebijakan pengendalian perizinan pembangunan sarana akomodasi pariwisata di Kabupaten Badung?

Adapun dalam penulisan ini, peneliti akan menampilkan tiga buah orisinalitas penyusunan jurnal ini, baik dari jurnal dan maupun tesis terdahulu yang pembahasannya berkaitan dengan kewenangan Pemerintah 
Daerah Kabupaten Badung dalam pengendalian pembangunan sarana akomodasi pariwisata, antara lain sebagai berikut : Jurnal Ilmiah Pariwisata karya Rossi Evita, I Nyoman Sirtha dan I Nyoman Sunarta (Mahasiswa Fakultas Pariwisata UNUD) yang berjudul Dampak Perkembangan Pembangunan Sarana Akomodasi Wisata Terhadap Pariwisata Berkelanjutan di Bali. Jurnal karya I Nyoman Ngurah Suwarnatha (Dosen Fakultas Hukum Universitas Pendidikan Nasional Denpasar) yang berjudul Tinjauan Konstitusi Kewenangan Pemerintah Daerah Kabupaten Badung dalam Mengeluarkan Kebijakan Pengendalian Pembangunan

Akomodasi Pariwista. Jurnal karya Imma Triana Mastuty, Piers Andreas Noak dan Ni Wayan Suprilliyani (Mahasiswa Fakultas Ilmu Sosial Ilmu Politik UNUD) yang berjudul Implementasi Kebijakan Pemerintah Provinsi Bali dalam Moratorium Pembangunan Infrastruktur Akomodasi Pariwisata Hotel di Kabupaten Badung. Dari jurnaljurnal yang telah disampaikan tersebut diatas, bahwa terkait penyusunan jurnal ini lebih mengetengahkan pada kewenangan Pemerintah Kabupaten Badung dalam pengendalian perizinan pembangunan sarana akomodasi pariwisata.

Secara garis besar dapat dikemukakan bahwa tujuan dari penelitian ini antara lain :

1. Untuk mengetahui sumber kewenangan

Pemerintah

Kabupaten Badung dalam pengendalian sarana akomodasi pariwisata.

2. Untuk mengetahui kebijakan pengendalian sarana akomodasi pariwisata di Pemerintah Kabupaten Badung.

3. Untuk mengetahui sejauh mana Peraturan Bupati (Perbup) Nomor 36 Tahun 2014 dapat membatasi pembangunan sarana akomodasi pariwisata khususnya di Kabupaten Badung.

\section{METODE PENELITIAN}

Jenis penelitian yang digunakan dalam penelitian ini adalah penelitian hukum normatifyaitu penelitian hukum yang dilakukan (terutama) terhadap bahan hukum primer dan sekunder, sepanjang bahan-bahan tersebut mengandungkaidahhukum ${ }^{5}$.Penelitian Normatif tersebut mencakup beberapa hal di dalamnya, yaitu : Penelitian terhadap asas-asas hukum, Penelitian terhadap sistematika hukum, Penelitian terhadap taraf sinkronisasi hukum atau peraturan perundang-undangan baik secara vertical maupun horizontal, Penelitian perbandingan hukum maupun Penelitian sejarah hukum. Dalam kaitannya dengan penelitian ini, maka aspek normatif yang dimaksud adalah melakukan penelitian terhadap sumber kewenangan Pemerintah Daerah Kabupaten Badung dalam

5 Soerjono Soekanto, 2008, Penelitian Hukum Normatif Suatu Tinjauan Singkat, Rajawali Pers, Jakarta, hlm. 70 
mengeluarkan kebijakan pengendalian perizinan pembangunan sarana akomodasi pariwisata.

Jenis pendekatan yang digunakan adalah pendekatan perundangundangan (The Statue Approach) dan Pendekatan Analisis Konsep Hukum (AnaliticalandConceptualApproach). ${ }^{6}$ Dalam hal ini peneliti melakukan analisis terhadap peraturan-peraturan yang terkait dengan kewenangan Pemerintah Daerah Kabupaten Badung dalam mengeluarkan kebijakan pengendalian perizinan pembangunan sarana akomodasi pariwisata.

Sumber bahan hukum yang digunakan adalah bahan hukum primer yang berupa peraturan perundangundangan dan bahan hukum sekunder yang berupa buku, majalah, artikel dan lain sebagainya. Adapun teknik pengolahan bahan hukum yaitu setelah bahan hukum terkumpul kemudian di analisis menggunakan teknik deskriptif kualitatif yaitu dengan memaparkan bahan hukum primer dan bahan hukum sekunder apa adanya. ${ }^{7}$ Adapun bahan hukum primer yang dipergunakan antara lain :

(1) Undang-Undang Dasar Negara Republik Indonesia Tahun 1945;

6 Dalam penelitian hukum normative dikenal berbagai jenis pendekatan: Case Approach, Statute Approach, Historical Approach, Conceptual Approach, serta Comparative Approach. Lihat Peter Mahmud Marzuki, 2005, Penelitian Hukum, Prenada Media, Jakarta, hlm. 96-155

7 Amirruddin dan Zainal Asikin, 2003, Pengantar Metode Penelitian Hukum, Rajawali Press, Jakarta, hlm..68.
(2) Undang-Undang Nomor 26 Tahun 2007 Tentang Penataan Ruang;

(3) Undang-Undang Nomor 32 Tahun 2009 Tentang Perlindungan dan Pengelolaan Lingkungan Hidup;

(4) Undang-Undang Nomor 23 Tahun 2014 Tentang Pemerintahan Daerah;

(5) Peraturan Pemerintah Nomor 26 Tahun 2008 tentang Rencana Tata Ruang Wilayah Nasional;

(6) Peraturan Daerah Provinsi Bali Nomor 16 tahun 2009 Tentang Rencana Tata Ruang Wilayah Provinsi Bali; dan

(7) Peraturan Daerah Provinsi Bali Nomor 26 tahun 2013 Tentang Rencana Tata Ruang Wilayah Kabupaten Badung.

Bahan hukum sekunder yang dipergunakan dalam penelitian ini antaralain, buku-bukuataupunliteraturliteratur, jurnal-jurnal hukum, media cetak dan media elektronik. Dalam penelitian ini juga mempergunakan bahan hukun tersier berupa kamus hukum, internet dan lain-lain.

Untuk memperoleh data yang relevan dengan permasalahan yang diteliti, dikaitkan dengan jenis penelitian hukum normatif, maka teknik pengumpulan data dimulai dengan menginventarisasi peraturan perundang-undangan yang berkaitan dengan kebijakan pengendalian perizinan pembangunan sarana akomodasi pariwisata. Setelah itu 
dibuat intisarinya, lalu peraturan perundangan tersebut dicocokkan dengan pelaksanaan dan kenyataannya di lapangan dengan mengumpulkan dokumen yang berkaitan dengan permasalahan yang diteliti. Teknik analisis bahan hukum menggunakan teknik deskripsi dengan memaparkan terlebih dahulu kemudian dianalisa dan selanjutnya disimpulkan.

\section{HASIL DAN PEMBAHASAN}

\subsection{Sumber kewenangan}

Pemerintah Daerah Kabupaten Badung dalam pengendalian perizinan pembangunan sarana akomodasi pariwisata. Wewenang merupakan bagian yang sangat penting dalam Hukum Tata Pemerintahan (Hukum Administrasi), karena pemerintahan baru dapat menjalankan fungsinya atas dasar wewenang yang diperolehnya. Keabsahan tindakan pemerintahan diukur berdasarkan wewenang yang diatur dalam Peraturan perundangundangan. Perihal kewenangan dapat dilihat dari Konstitusi Negara yang memberikan legitimasi kepada Badan Publik dan Lembaga Negara dalam menjalankan fungsinya. Wewenang adalah kemampuan bertindak yang diberikan oleh undang-undang yang berlaku untuk melakukan hubungan dan perbuatan hukum. ${ }^{8}$.

Dalam negara hukum, kewenangan pemerintahan itu berasal

\footnotetext{
SF. Marbun, 1997, Peradilan Administrasi Negara dan Upaya Administrasi di Indonesia, Liberty, Yogyakarta, hlm. 154.
}

dari peraturan perundang-undangan yang berlaku, dan ini berarti sumber wewenang bagi pemerintah adalah peraturan perundang-undangan. Secara teoritis, kewenangan yang bersumber dari peraturan perundang-undangan tersebut dapat diperoleh melalui 3 cara, yaitu: ${ }^{9}$

a. Atribusi, yaitu pemberian wewenang pemerintahan oleh pembuat undang-undang kepada organ pemerintahan .

b. Delegasi, yaitu pelimpahan wewenang pemerintahan dari satu organ pemerintahan kepada organ pemerintahan lainnya. Suatu delegasi selalu didahului oleh adanya suatu atribusi wewenang.

c. Mandat, bahwa terjadinya suatu mandat adalah ketika organ pemerintahan mengijinkan kewenangannya dijalankan oleh organ lain atas namanya.

Setiap kebijakan atau tindak pemerintahan harus bersumber atau bertumpu atas kewenangan yang sah, demikian juga mengenai kewenangan dalam pengendalian perizinan pembangunan sarana akomodasi pariwisata.

Negara menyelenggarakan penataan ruang untuk sebesarbesar kemakmuran rakyat. Dalam melaksanakan tugas sebagaimana dimaksud di atas, negara memberikan

\footnotetext{
Sutarman, 2007, Kerjasana Antar Daerah Dalam Pelayanan Perizinan Dan Penegakan Hukum Penangkapan Ikan Di Wilayah Laut, Disertasi Airlangga., hlm. 129
} 
kewenangan penyelenggaraan penataan ruang kepada Pemerintah dan Pemerintah Daerah. Penyelenggaraan penataan ruang sebagaimana dimaksud di atas dilakukan dengan tetap menghormati hak yang dimiliki orang sesuai dengan ketentuan peraturan perundang-undangan.

Pada Pasal 11 Undang-undang Nomor 26 Tahun 2007 tentang Penataan Ruang disebutkan mengenai Wewenang Pemerintah Daerah Kabupaten/Kota, adapun wewenang pemerintah daerah Kabupaten/Kota dalam penyelenggaraan penataan ruang meliputi:

a. pengaturan, pembinaan, dan pengawasan terhadap pelaksanaan penataan ruang wilayah kabupaten/kota dan kawasan strategis kabupaten/ kota;

b. pelaksanaan penataan ruang wilayah kabupaten/kota;

c. pelaksanaan penataan ruang kawasan strategis kabupaten/ kota; dan

d. kerja sama penataan ruang antar kabupaten/ kota.

Wewenang pemerintah daerah Kabupaten/Kota dalam pelaksanaan penataan ruang wilayah Kabupaten/ Kota sebagaimana dimaksud diatas meliputi:

a. perencanaan tata ruang wilayah kabupaten/ kota;

b. pemanfaatan ruang wilayah kabupaten/kota; dan

c. pengendalian pemanfaatan ruang wilayah kabupaten/kota.
Dalam pelaksanaan penataan ruang kawasan strategis Kabupaten/ Kota sebagaimana dimaksud diatas, pemerintah daerah Kabupaten/Kota melaksanakan:

a. penetapan kawasan strategis kabupaten/kota;

b. perencanaan tata ruang kawasan strategis kabupaten/kota;

c. pemanfaatan ruang kawasan strategis kabupaten/kota; dan

d. pengendalian pemanfaatan ruang kawasan strategis kabupaten/ kota.

Dalam melaksanakan kewenangan sebagaimana dimaksud diatas, pemerintah daerah Kabupaten/ Kota mengacu pada pedoman bidang penataan ruang dan petunjuk pelaksanaannya. Dalam pelaksanaan wewenang sebagaimana dimaksud tersebut diatas, pemerintah daerah kabupaten/kota:

a. menyebarluaskan informasi yang berkaitan dengan rencana umum dan rencana rinci tata ruang dalam rangka pelaksanaan penataan ruang wilayah kabupaten/kota; dan

b. melaksanakan standar pelayanan minimal bidang penataan ruang. Dalam hal pemerintah daerah kabupaten/kota tidak dapat memenuhi standar pelayanan minimal bidang penataan ruang, pemerintah daerah provinsi dapat mengambil langkah penyelesaian sesuai dengan ketentuan peraturan perundang-undangan. 
Pengendalian pemanfaatan ruang merupakan suatu upaya untuk menjamin tercapainya tujuan dan sasaran rencana tata ruang wilayah. Pengendalian tata ruang wilayah berpedoman pada arahan-arahan yang ditetapkan dalam rencana struktur tata ruangwilayahdanrencanapemanfaatan ruang pada tingkat Provinsi dan Kabupaten. Dalam Rencana Tata Ruang Wilayah (RTRW) Kabupaten Badung, Ketentuan Pengendalian Pemanfaatan Ruang digunakan sebagai acuan dalam pelaksanaan Pengendalian Pemanfaatan Ruang Wilayah Kabupaten. Adapun ketentuan Pengendalian Pemanfaatan Ruang Wilayah Kabupaten, terdiri atas : ${ }^{10}$

1. ketentuan umum Peraturan Zonasi;

2. ketentuan perizinan;

3. ketentuan pemberian insentif dan disinsentif; dan

4. arahan sanksi.

Peraturan zonasi sebagaimana dimaksud disusun sebagai pedoman pengendalian pemanfaatan ruang. Peraturan zonasi disusun berdasarkan rencana rinci tata ruang untuk setiap zona pemanfaatan ruang. Peraturan zonasi ditetapkan dengan:

a. peraturan pemerintah untuk arahan peraturan zonasi sistem nasional;

10 Pasal 60 Rencana Tata Ruang Wilayah Kabupaten Badung 2013-2033, Lembaran Daerah Kabupaten Badung Tahun 2013 Nomor 26. b. peraturan daerah provinsi untuk arahan peraturan zonasi sistem provinsi; dan

c. peraturan daerah kabupaten/kota untuk peraturan zonasi.

Perijinan pemanfaatan ruang dimaksudkan sebagai upaya penertiban pemanfaatan ruang sehingga setiap pemanfaatan ruang harus dilakukan sesuai dengan rencana tata ruang. Ijin pemanfaatan ruang diatur dan diterbitkan oleh Pemerintah dan Pemerintah Daerah sesuai dengan kewenangannya masing-masing. Pemanfaatan ruang yang tidak sesuai dengan rencana tata ruang, baik yang dilengkapi dengan ijin maupun yang tidak memiliki ijin, dikenai sanksi administratif, sanksi pidana kurungan/ penjara, dan/atau sanksi pidana denda. Pemberian insentif dimaksudkan sebagai upaya untuk memberikan imbalan terhadap pelaksanaan kegiatan yang sejalan dengan rencana tata ruang, baik yang dilakukan oleh masyarakat maupun oleh pemerintah daerah. Bentuk insentif tersebut antara lain dapat berupa : keringanan pajak, pembangunan prasarana dan sarana (infrastruktur), pemberian kompensasi, kemudahan prosedur perijinan, dan pemberian penghargaan. Disinsentif dimaksudkan sebagai perangkat untuk mencegah, membatasi pertumbuhan, dan/atau mengurangi kegiatan yang tidak sejalan dengan rencana tata ruang, yang antara lain dapat berupa : pengenaan pajak yang tinggi, pembatasan penyediaan prasarana dan 
sarana, serta pengenaan kompensasi dan penalti.

Pengenaan sanksi merupakan salah satu upaya pengendalian pemanfaatan ruang, dimaksudkan sebagai perangkat tindakan penertiban atas pemanfaatan ruang yang tidak sesuai dengan rencana tata ruang dan peraturan zonasi. Dalam undangundang ini pengenaan sanksi tidak hanya diberikan kepada pemanfaatan ruang yang tidak sesuai dengan ketentuan perijinan pemanfaatan ruang, tetapi dikenakan pula kepada pejabat pemerintah yang berwenang yang menerbitkan ijin pemanfaatan ruang yang tidak sesuai dengan rencana tata ruang.

\subsection{Kebijakan perizinan}

pengendalian pembangunan sarana akomodasi pariwisata di Kabupaten Badung.

Dalam studi kebijakan publik terdapat banyak model implementasi kebijakan publik. Menurut Edward III dalam Widodo ${ }^{11}$ ada empat faktor atau variabel yang mempengaruhi suatu keberhasilan atau kegagalan implementasi kebijakan. Empat variabel dan faktor itu adalah komunikasi (communications), sumber daya (resources), disposisi (disposition), dan struktur birokrasi (bureaucratic structure).

\section{Kebijakan}

pengendalian perizinan ini dilaksanakan bertujuan

11 Widodo, Joko, 2006, Analisis Kebijakan Publik. Konsep dan Aplikasi Analisis Proses Kebijakan Publik, Sidoarjo, Bayumedia Publishing, hlm.96 untuk mengetahui sekaligus mengendalikan apakah dan bagaimanakah dalam pelaksanaannya suatu tindakan pembangunan telah tercapai kesesuaian ataukah terjadi penyimpangan terhadap rencana awal yang telah ditetapkan. Aspek yang dimasukkan dalam pertimbangan ini antara lain ialah bentuk fisik, fungsi waktu atau tahapan pelaksanaan, fungsi pembiayaan dan sebagainya. disamping itu dalam pengendalian pemanfaatan ruang diperlukan analisis terhadap dampak yang ditimbulkan oleh pelaksanaan suatu rencana pembangunan. Analisis terhadap dampak yang ditimbulkan mencakup dampak positif maupun dampak negatif yang muncul ditinjau dari aspek ekonomi, sosial budaya, lingkungan hidup dan sebagainya. Selanjutnya dalam pengendalian pemanfaatan ruang ini diharapkan mampu memberikan atau menghasilkan umpan balik sebagai hasil evaluasi pengendalian pemanfaatan ruang yang berperan sebagai input bagi tahap pemanfaatan ruang dan/atau tahap perencanaan tata ruang dalam proses siklus berikutnya. Kegiatan pengendalian pemanfaatan ruang dilakukan dalam bentuk pengawasan dan penertiban kegiatan pemanfaatan ruang. Tindakan pengawasan akan merupakan dasar tindakan penertiban untuk menyelesaikan masalah tata ruang. Kegiatan pengendalian pemanfaatan ruang dapat menjadi:

1. Pengarahan lokasi kegiatan untuk kegiatan budidaya 
melalui mekanisme perijinan (untuk kawasan berskala besar) dengan pendekatan intensif dan disinsentif;

2. Pelarangan/pencegahan dilakukan kegiatan budidaya yang tidak sesuai dengan rencana;

3. Pembatasan kegiatan lain yang telah ada dengan ketentuan tidak dilakukan pengembangannya lebih lanjut;

4. Penyelesaian masalah tumpang tindih antar kegiatan budidaya (baik status/penguasaan lahan, proyek pembangunan, penggunaan lahan yang telah berlangsung lama) berdasarkan berbagai ketentuan perundangan yang berlaku;

5. Pengendalian pemanfaatan ruang dilakukan melalui penetapan peraturan zonasi, perijinan, pemberian insentif dan disinsentif, serta pengenaan sanksi.

RTRW Kabupaten Badung sebagai salah satu instrumen pengendalian wilayah akan menjadi efektif apabila pada tahap selanjutnya (tahap pelaksanaan rencana) dapat berfungsi sebagai arahan atau pedoman bagi program dan penyelenggaraan pembangunan sarana akomodasi pariwisata, baik yang diselenggarakan oleh instansi pemerintah maupun oleh perorangan maupun swasta. Tahap pelaksanaan rencana kawasan Kabupaten Badung pada dasarnya merupakan suatu proses pengendalian, yang memiliki tiga simpul utama kegiatan yang saling terkait, yaitu pengawasan, intervensi dan evaluasi. Ketiga aktivitas utama tersebut terpilah pada asas operasional, manajerial dan konseptual.

Persaingan dari para investor untuk mendirikan bangunan hotel dan kondotel di beberapa lokasi kawasan pariwisata di Kabupaten Badung dari tahun ke tahun terus meningkat secara signifikan. Pendirian bangunan hotel tersebut tidak serta merta berdiri begitu saja di pada kawasan pariwisata, namun dibutuhkan prosedur perizinan agar sebuah hotel dan kondotel tersebut dapat dibangun. Dalam pengertian umum berdasar Kamus Besar Bahasa Indonesia $(\mathrm{KBBI})$, perizinan diartikan sebagai hal pemberian izin. Izin itu sendiri dalam KBBI diartikan sebagai pernyataan mengabulkan (tidak melarang), atau persetujuan membolehkan. Dengan demikian, secara umum perizinan dapat diartikan sebagai hal pemberian pernyataan mengabulkan, atau persetujuan membolehkan. ${ }^{12}$ Menurut Spelt dan ten Berge, ada beberapa tujuan pemberian izin, yakni: ${ }^{13}$

1. Suatu keinginan untuk mengarahkan atau mengen-

12 Pusat Bahasa Depdikbud, Kamus Besar Bahasa Indonesa, Edisi Ketiga, Balai Pustaka, Jakarta, 2001, hlm.447.

13 Mr. N.M Spelt dan ten Berge dan Prof. Mr.J.B.J.M ten Berge, disunting oleh Dr. Philipus Hadjon, S.H., 1993, loc.cit. hlm. 4 dalam Y. Sri Pudyatmoko, Perizinan, Problem dan Upaya Pembenahan, Grasindo, Jakarta, hlm. 11 
dalikan pada aktivitas-aktivitas tertentu.

2. Untuk mencegah bahaya bagi lingkungan.

3. Adanya keinginan melindungi dari obyek-obyek tertentu.

4. Untuk membagi benda-benda yang sedikit.

5. Untuk mengarahkan dengan menyeleksi orang-orang dan aktivitas yang harus memenuhi syarat tertentu.

Dalam RTRW Kabupaten

Badung terkait Ketentuan Umum Perizinan diatur pada Pasal 94 yang menyebutkan bahwa Ketentuan Umum perijinan merupakan proses administrasi dan teknis yang harus dipenuhi sebelum kegiatan Pemanfaatan Ruang dilaksanakan, untuk menjamin kesesuaian Pemanfaatan Ruang dengan Rencana Tata Ruang, meliputi :

a. izin prinsip;

b. izin lokasi;

c. izin mendirikan bangunan; dan

d. izin lainnya.

Setiap orang yang melakukan segala bentuk kegiatan memanfaatkan ruang, pembangunan prasarana serta yang memerlukan tanah dalam rangka penanaman modal wajib memiliki IPR mengacu pada RTRWK. Terkait ketentuan teknis prosedural dalam pengajuan IPR dilaksanakan oleh instansi yang berwenang dengan mempertimbangkan rekomendasi dari BKPRD Kabupaten. Setiap pejabat Pemerintah Daerah yang berwenang menerbitkan Izin Pemanfaatan Ruang, dilarang menerbitkan izin yang tidak sesuai dengan RTRWK. Izin sebagai suatu ketetapan pada hakikatnya adalah tindakan hukum sepihak berdasarkan kewenangan publik yang memperbolehkan atau memperkenankan menurut hukum bagi seseorang/badan hukum untuk melakukan suatu kegiatan. ${ }^{14}$

Di tengah optimisme pembangunan dan persaingan usaha, pembangunan hotel dan kondotel sebagai sarana akomodasi pariwisata yang berkualitas semakin sulit dikendalikan. Hotel-hotel dibangun tanpa memperhatikan batasan lahan yang dipergunakan untuk membangun hotel dan kondotel, sehingga tidak jarang dulunya berfungsi sebagai villa atau rumah tinggal dan toko berubah fungsi menjadi hotel maupun hotel melati. Hal ini dipandang penting, sehingga diperlukan regulasi terkait standarisasi luasan lahan untuk pembangunan hotel dan kondotel di kabupaten Badung, terkait hal tersebut Pemerintah Kabupaten Badung menerbitkan Peraturan Bupati(Perbup) Nomor 36 tahun 2014 tentang Standar Minimal Luas Lahan dan Luas Kamar serta Fasilitas Penunjang Hotel dan Kondotel. Peraturan Bupati (Perbup) Nomor 36 tahun 2014 ini dalam rangka mengantisipasi pertumbuhan

14 I Made Arya Utama, 2007, Hukum Lingkungan, Sistem Hukum Perizinan Berwawasan Lingkungan Untuk Pembangunan Berkelanjutan, Pustaka Sutra, Bandung, hlm.45. 
pembangunan kepariwisataan di Kabupaten Badung, khususnya terhadap pembangunan sarana akomodasi hotel dan kondotel serta semakin menjamurnya konsep-konsep city hotel yang secara estiteka kurang nyaman di dalam rangka menyediakan akomodasi pariwisata yang berkualitas, maka perlu pengendalian perizinan pembangunan jumlah hotel dan kondotel melalui standarisasi luasan lahan, luas kamar dan fasilitas penunjangnya. Dengan dikeluarkannya Peraturan Bupati ini diharapkan permohonan izin pembangunan hotel dan kondotel pun semakin terkendali pula, disamping menindak lanjuti dari Surat Edaran (SE) Gubernur Bali No.570/1665/BPM tanggal 27 Desember 2010 tentang penghentian sementara pembangunan akomodasi pariwisata dan penanaman modal untuk bidang jasa akomodasi, diharapkan dengan diterbitkannya Peraturan Bupati ini pembangunan sarana akomodasi pariwisata khususnya hotel dan kondotel mempunyai kualitas dengan estetika budaya bali yang mampu bersaing dengan sarana akomodasi lainnya yang ada seluruh Indonesia serta mampu memberikan kenyamanan bagi wisatawan yang berkunjung ke wilayah Kabupaten Badung.

Adapun kebijakan Pemerintah Kabupaten Badung dalam pengendalian perizinan pembangunan sarana akomodasi pariwisata seperti tertuang dalam Peraturan Bupati
(Perbup) Nomor 36 tahun 2014 dalam Pasal 2 yang menyebutkan bahwa Luas lahan untuk pembangunan hotel dan kondotel untuk wilayah Kecamatan Kuta ditetapkan minimal seluas 50 (lima puluh) are, wilayah Kecamatan Kuta Utara ditetapkan minimal seluas 75 (tujuh puluh lima) are dan untuk wilayah Kecamatan Kuta Selatan ditetapkan minimal seluas 100 (seratus) are. Sedangkan pada Pasal 4 disebutkan bahwa Standar minimal luas kamar hotel dan kondotel termasuk kamar mandi ditetapkan $32 \mathrm{~m}^{2}$ (tiga puluh dua meter persegi).

Kebijakan pengendalian sarana akomodasi pariwisata seperti yang disebutkan diatas, diharapkan mampu mengendalikan perkembangan pembangunan hotel dan kondotel di Kabupaten Badung, sehingga konsep pembangunan pariwisataberkelanjutan dapat berjalan secara optimal. Mengingat konsep pembangunan pariwisata berkelanjutan tersebut adalah bertujuan untuk menjaga keberlangsungan lingkungan dan aktivitas pariwisata sehingga nantinya mampu memberikan dampak positif bagi kunjungan wisatawan ke Kabupaten Badung. Dengan standarisasi pembangunan sarana akomodasi diharapkan wisatawan yang datang adalah wisatawan yang berkualitas dengan destinasi pariwisata yang berkualitas serta fasilitas sarana akomodasi yang nyaman dan bersih. Disamping itu, Perkembangan pembangunan industri pariwisata di 
Kabupaten Badung diharapkan dapat mengoptimalkan manfaatnya untuk kepentingan kesejahteraan masyarakat. Pembangunan industri pariwisata yang berorientasi pada pemberdayaan masyarakat yang mengutamakan peran dan partisipasi masyarakat lokal sebagai subjek pembangunan industri pariwisata khusunya di Kabupaten Badung.

\section{KESIMPULAN}

Berdasarkan

uraian

pembahasan di atas dapat disimpulkan sebagai berikut:

1. Bahwa Pada Pasal 11 Undangundang Nomor 26 Tahun 2007 tentang Penataan Ruang menyebutkan bahwa Wewenang Pemerintah Daerah Kabupaten/ Kota meliputi: perencanaan tata ruang wilayah kabupaten/ kota, pemanfaatan ruang wilayah kabupaten/kota dan pengendalian pemanfaatan ruang wilayah kabupaten/kota. Sedangkan dalam Rencana Tata Ruang Wilayah (RTRW) Kabupaten Badung, kewenangan Kabupaten Badung dalam pengendalian pemanfaatan ruang yang digunakan sebagai acuan dalam pelaksanaan pengendalian pemanfaatan ruang di wilayah Kabupaten Badung yaitu menyusun ketentuan umum Peraturan Zonasi, ketentuan perizinan, ketentuan pemberian insentif dan disinsentif dan arahan sanksi.
2. KebijakanPemerintahKabupaten Badung dalam pengendalian perizinan pembangunan sarana akomodasi pariwisata seperti tertuang dalam Peraturan Bupati (Perbup) Nomor 36 tahun 2014 dalam Pasal 2 yang menyebutkan bahwa Luas lahan untuk pembangunan hotel dan kondotel untuk wilayah Kecamatan Kuta ditetapkan minimal seluas 50 (lima puluh) are, wilayah Kecamatan Kuta Utara ditetapkan minimal seluas 75 (tujuh puluh lima) are dan untuk wilayah Kecamatan Kuta Selatanditetapkanminimalseluas 100 (seratus) are. Sedangkan pada Pasal 4 disebutkan bahwa Standar minimal luas kamar hotel dan kondotel termasuk kamar mandi ditetapkan $32 \mathrm{~m}^{2}$ (tiga puluh dua meter persegi).

\section{DAFTAR PUSTAKA}

\section{Buku}

Amirruddin dan Zainal Asikin, 2003, Pengantar Metode Penelitian Hukum, Rajawali Press, Jakarta. Badan Pusat Statistik Kabupaten Badung, Badung Dalam Angka Tahun 2015, Badung.

Mr. N.M Spelt dan ten Berge dan Prof. Mr.J.B.J.M ten Berge, disunting oleh Dr. Philipus Hadjon, S.H., 1993, loc.cit. hlm. 4 dalam Y. Sri Pudyatmoko, Perizinan, Problem dan Upaya Pembenahan, Grasindo, Jakarta. 
Peter Mahmud Marzuki, 2005, Penelitian Hukum, Prenada Media, Jakarta.

Pusat Bahasa Depdikbud, 2001, Kamus Besar Bahasa Indonesa, Edisi Ketiga, Balai Pustaka, Jakarta.

Soerjono Soekanto, 2008, Penelitian Hukum Normatif Suatu Tinjauan Singkat, Rajawali Pers, Jakarta.

SF. Marbun, 1997, Peradilan Administrasi Negara dan Upaya Administrasi di Indonesia, Liberty, Yogyakarta.

Sutarman, 2007, Kerjasana Antar Daerah Dalam Pelayanan Perizinan Dan Penegakan Hukum Penangkapan Ikan Di Wilayah Laut, Disertasi Airlangga.

Widodo, Joko, 2006, Analisis Kebijakan Publik. Konsep dan Aplikasi Analisis Proses Kebijakan Publik, Bayumedia Publishing, Sidoarjo.

\section{Jurnal}

Diah Fitriani, Penjabaran Hak Tenaga Kerja Perempuan Atas Upah Dan Waktu Kerja Dalam Peraturan Perusahaan Dan Perjanjian Kerja, Jurnal Magister Hukum Udayana (Udayana Master Law Journal), vo.4, no. 2, Tahun 2015, Edisi Juli 2015.

Ni Ketut Supasti Dharmawan dan Wayan Wiryawan, Keberadaan dan Implikasi Prinsip MFN dan NT dalam Pengaturan Hak Kekayaan Intelektual Di
Indonesia, Magister Hukum Udayana, vol. 6, no.2, Tahun 2014, Edisi Mei 2014.

Putu Eva Laheri, Tanggung Jawab Negara Terhadap Kerugian Wisatawan Berkaitan Dengan Pelanggaran Hak Berwisata Sebagai Bagian Dari Hak Asasi Manusia, Jurnal Magister Hukum Udayana (Udayana Master Law Journal), vol.4, no. 1, Tahun 2015, Edisi Mei 2015.

\section{Media Cetak}

Republika, 19 Pebruari 2016, Kadin Desak Moratorium Hotel di Bali Selatan.

Tribun Bali, 13 April 2016, Moratorium Hotel di Bali Selatan sulit Diterapkan.

\section{Peraturan Perundang-undangan:}

Undang Undang Dasar Negara Republik Indonesia Tahun 1945.

Undang-Undang Nomor 26 Tahun 2007 Tentang Penataan Ruang (Lembaran Negara Republik Indonesia Tahun 2007 Nomor 68).

Undang-Undang Nomor 23 Tahun 2014 Tentang Pemerintahan Daerah (Lembaran Negara Republik Indonesia Tahun 2014 Nomor 244).

Peraturan Pemerintah Nomor 26 Tahun 2008 tentang Rencana Tata Ruang Wilayah Nasional (Lembaran Negara Republik 
Indonesia Tahun 2008 Nomor 48).

Peraturan Daerah Provinsi Bali Nomor

16 tahun 2009 Tentang Rencana

Tata Ruang Wilayah Provinsi

Bali (Lembaran Daerah Provinsi

Bali Tahun 2009 Nomor 16).

Peraturan Daerah Kabupaten Badung

Nomor 26 tahun 2013 Tentang

Rencana Tata Ruang Wilayah

Kabupaten Badung (Lembaran

Daerah Kabupaten Badung

Tahun 2013 Nomor 26). 